\title{
IL33 and Mast Cells - The Key Regulators of Immune Responses in Gastrointestinal Cancers?
}

\author{
Moritz F. Eissmann*, Michael Buchert and Matthias Ernst* \\ Olivia Newton-John Cancer Research Institute, and La Trobe University School of Cancer Medicine, Heidelberg, VIC, Australia
}

\section{OPEN ACCESS}

Edited by:

Giovanna Schiavoni,

Istituto Superiore di Sanità (ISS), Italy

Reviewed by:

Khashayarsha Khazaie,

Mayo Clinic College of Medicine \&

Science, United States

Philippe Krebs,

University of Bern, Switzerland

*Correspondence:

Moritz F. Eissmann

moritz.eissmann@onjcri.org.au

Matthias Ernst

matthias.ernst@onjcri.org.au

Specialty section:

This article was submitted to Cancer Immunity and Immunotherapy,

a section of the journal

Frontiers in Immunology

Received: 14 March 2020 Accepted: 29 May 2020 Published: 03 July 2020

Citation:

Eissmann MF, Buchert $M$ and Ernst $M$ (2020) IL33 and Mast Cells - The Key Regulators of Immune Responses in

Gastrointestinal Cancers?

Front. Immunol. 11:1389.

doi: 10.3389/fimmu.2020.01389
The Interleukin (IL-)1 family IL33 is best known for eliciting type 2 immune responses by stimulating mast cells (MCs), regulatory T-cells (Tregs), innate lymphoid cells (ILCs) and other immune cells. MCs and IL33 provide critical control of immunological and epithelial homeostasis in the gastrointestinal (Gl) tract. Meanwhile, the role of MCs in solid malignancies appears tissue-specific with both pro and anti-tumorigenic activities. Likewise, IL33 signaling significantly shapes immune responses in the tumor microenvironment, but these effects remain often dichotomous when assessed in experimental models of cancer. Thus, the balance between tumor suppressing and tumor promoting activities of IL33 are highly context dependent, and most likely dictated by the mixture of cell types responding to IL33. Adding to this complexity is the promiscuous nature by which MCs respond to cytokines other than IL33 and release chemotactic factors that recruit immune cells into the tumor microenvironment. In this review, we integrate the outcomes of recent studies on the role of MCs and IL33 in cancer with our own observations in the Gl tract. We propose a working model where the most abundant IL33 responsive immune cell type is likely to dictate an overall tumor-supporting or tumor suppressing outcome in vivo. We discuss how these opposing responses affect the therapeutic potential of targeting MC and IL33, and highlight the caveats and challenges facing our ability to effectively harness MCs and IL33 biology for anti-cancer immunotherapy.

Keywords: interleukin 33 (IL33), mast cell (MC), innate immunity, ST2, gastrointestinal (GI) malignancies, tumor microenvironment (TME), therapy targets, cytokine signaling

\section{INTRODUCTION}

The tumor microenvironment (TME) is a complex collection of cellular and extra cellular matrix (ECM) components. Interactions and communications between the various components of the TME are orchestrated by a multitude of signaling molecules, including the cytokine interleukin (IL)33. IL33 was first discovered in 2003 as a nuclear factor in HEVEC cells (NF-HEV) (1) and later identified as an IL1 family cytokine and ligand for the interleukin 1 receptor like 1 receptor (IL1RL1, or commonly referred to as ST2) (2).

IL33 is expressed in fibroblasts, endothelial and epithelial cells $(1,3,4)$ as well as in many cancer cells [reviewed in $(5,6)]$. Depending on stimulation or disease context, this cytokine is produced by additional cells such as MCs (7), dendritic cells, macrophages, neutrophils, eosinophils, B cells and red blood cells (8-11). Anatomically, the expression of IL33 is highest in barrier tissues like the skin, the air ways and the GI tract, where IL33 release activates innate and adaptive immune 
responses upon tissue injury or various infections [reviewed in (12)]. Indeed, tissue resident innate immune cells are the proposed first responder for released IL33, and MCs are present at all these environment-tissue interfaces (13). In general, necrotic or necroptotic cell death is required for its release (14-21), nevertheless, multiple studies suggest release of IL33 from living cells (22-25), suggesting various modes of active secretion and passive release with and without necrotic/necroptotic cell death depending on cell type and stimuli. Further research is required to unravel the exact mechanisms of IL33 release.

IL33 cytokine exerts its activity via binding to a heterodimeric receptor consisting of its primary receptor ST2 and a co-receptor, IL1 receptor accessory protein (IL1RAP) $(26,27)$ triggering downstream signaling pathways including MYD88, IRAK1/4, MAP kinases and NF-kB $(2,12)$. Importantly, the various biological outputs following engagement of the IL33-ST2 axis are heavily dictated by the cellular context, which we will further summarize in this review, with a special focus on interaction and importance the innate-immune mast cells for IL33 signaling in cancer. Besides acting as an extracellular ligand conferring activity through its cognate ST2 receptor on targets cells, ST2independent nuclear IL33 can act as transcriptional repressor in fibroblast, endothelial and immune cells $(28,29)$. Likewise, nuclear IL33 also promotes immune suppressive functions independent of ST2 in regulatory T (Tregs) cells (30), and cell intrinsic IL33 plays a role in B cell development (31).

\section{IL33-RESPONSIVE CELLS IN THE TUMOR MICROENVIRONMENT}

Since the identification of ST2 as the cognate receptor of IL33, various cell types have been shown to express ST2 and to respond to IL33 stimulation. However, there is a significant difference in the quality and quantity of ST2 expression among various cell types. Innate lymphoid cell type 2 (ILC2), Tregs and MCs express the ST2-receptor constitutively, while all other cell types that respond to extracellular IL33 are either ST2 negative at steadystate and only induce ST2 expression upon activation, or express ST2 on minor cell subsets in specific biological processes in a tissue-dependent manner (32).

\section{ILC2 Cells}

A significant subset of innate lymphoid cell type 2 (ILC2) are constitutive ST2 expressers. However, the proportion of ST2 positive ILC2s can vary depending on tissue origin and disease context (32-37). Stimulation of ILC2s by IL33/ST2-signaling is critical for their activation, induces their expansion within tissues and triggers secretion of the type 2 cytokines IL-5 and IL-13. This classic type 2 (innate) immune response contributes to antihelminth immunity, lipid metabolism and to the development of various allergic diseases such as asthma, atopic dermatitis, allergic rhinitis, and chronic rhinosinusitis (12, 13, 38-40). Recently, it was reported that IL33-activated tumor infiltrating ILC2s (TILC2) restrict pancreatic tumor growth. Moreover, IL33 induces the expression of inhibitory checkpoint receptor PD-1 in TILC2s. Antibody-mediated PD-1 blockade leads to TILC2 expansion and activation, resulting in augmented anti-tumor immunity, and enhanced tumor control (41).

\section{Treg Cells}

Depending on the tissue and disease setting, a significant proportion of Tregs constitutively express the ST2 receptor (32-37). IL-33/ST2 signaling in Tregs has been shown to promote Treg frequency and immunosuppressive capacity in colitis and tissue injury models as well as graft vs. host disease $(35,42)$. In cancer, IL33/ST2 signaling in Tregs seems particularly important in colon cancer, where the frequency of ST2-expressing Tregs is higher and ST2-expression is upregulated compared to normal colon tissue. Signaling through the ST2 receptor can increase frequency, activity and migratory potential of Tregs, which is associated with increased colonic tumor burden (43-45). However, there are also studies that demonstrate increased Treg density upon genetic ST2 ablation (34).

\section{Mast Cells}

While MCs can confer their functions through cell-cell contacts, their predominant way of shaping their cellular environment occurs via release of preformed or newly synthesized mediators. These paracrine acting molecules include growth factors, proteases, leukotrienes, cytokines and chemokines which in turn modulate biological processes and responses including: tissue remodeling, angiogenesis, pro/anti-inflammatory responses, immunosuppression, and cellular proliferation, survival, recruitment, maturation and differentiation $(46,47)$.

MCs provide critical nodes for IL33 signaling in innate immune cells. In external surface organs, where epithelial cells express high levels of IL33, the number of MCs is highest (48). MC's are first responders during infections, where IL33 acts as an alarmin following its release as a cellular danger signals (49). The dual importance of IL33 and MCs in allergies is well established (50), yet critical roles for the IL33-MC axis have also been uncovered in allergic, autoimmune, inflammatory disease as well as cancer and other diseases $(51,52)$. In addition, MCs can potentiate the biological impact of IL33, because chymases and tryptases released by activated MCs process full-length IL33 into a truncated and biologically more active mature protein (53). In addition, MCs have been described to also produce IL33 (7).

MCs appear to be the only cell type which constitutively express high levels of ST2 independent of their tissue origin or maturation/activation status $(33,54)$. Importantly, activation of MCs by IL33 leads to the release of a plethora of factors that act on various cell types in the TME and influence their recruitment, rate of proliferation and their state of activation, differentiation and polarization (Figure 1) (46, 55-65).

The striking overlap of cell types which respond to IL33 and mast cell-released mediators highlights the importance of the IL33-MC axis for the biological outcome and demonstrates the potential of MCs as amplifiers and regulators of IL33-mediated processes. However, most past studies have investigated the roles of IL33/ST2 and of MCs separately. We and others have begun to better integrate these closely related aspects of innate cell biology in the context of GI cancer, since this organ system is known for both high IL33 expression and high density of MCs. 


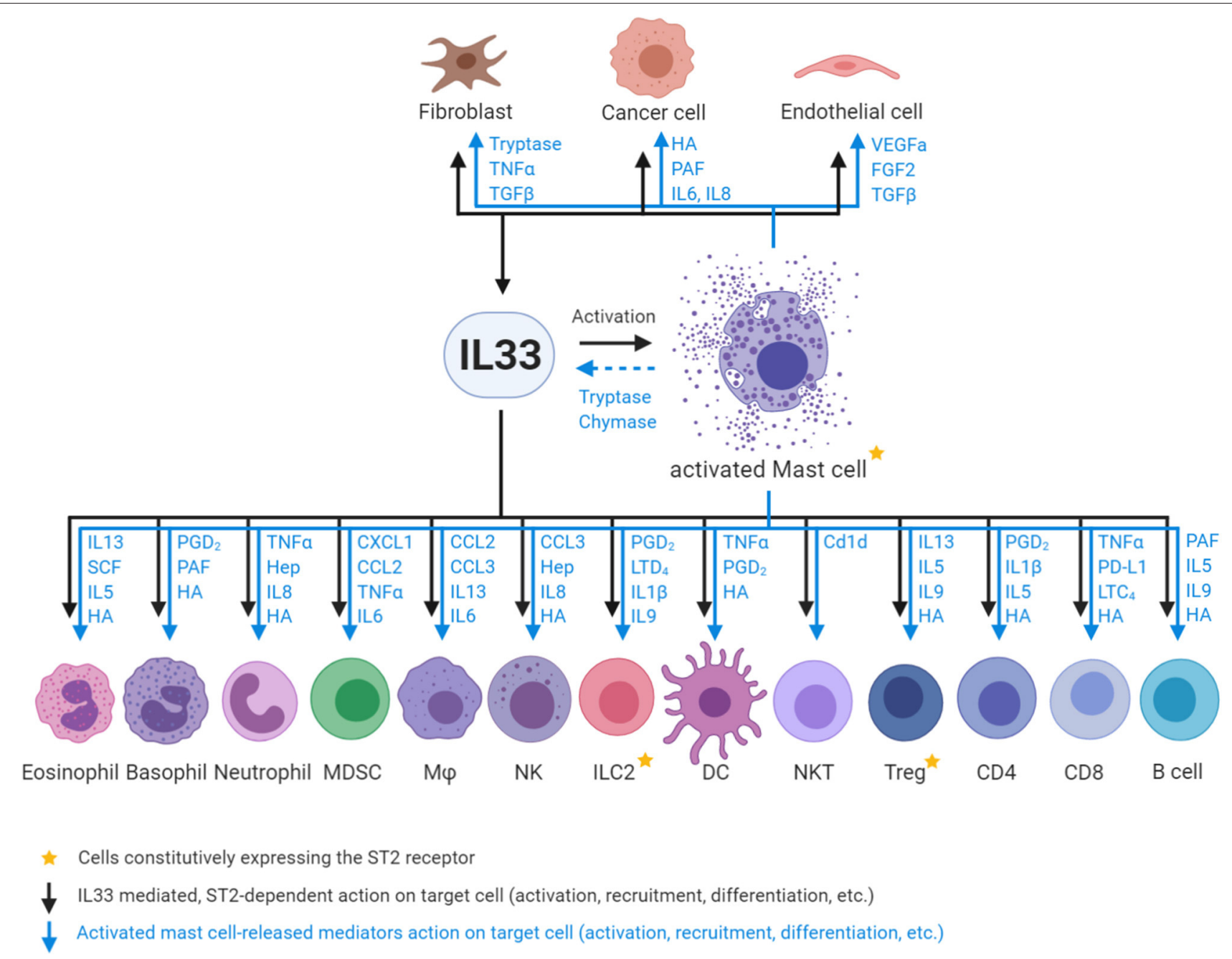

FIGURE 1 | Interactions between IL33, activated MCs and ST2-positive responder cells. Fibroblasts, endothelial and epithelial/tumor cells are the major source of IL33 in the tumor microenvironment, and can in turn be stimulated by IL33. IL33 activates MCs and in turn MC -released chymases/tryptases cleave full length IL33 into highly active mature IL33. Subsequently, both IL33 (via ST2 receptor binding on target cells) and activated MC (via mediator release; depicted in blue) action innate immune cells: eosinophils, basophils, neutrophils, myeloid derived suppressor cells (MDSC), macrophages (M申), natural killer cells (NK), type 2 innate lymphoid cells (ILC2), dendritic cells (DC), and adaptive immune cells: natural killer T cells (NKT), regulatory T cells (Treg), CD4 T cell subsets (Th1/2/17), CD8T cells (CD8), and B cells. Mast cell mediator abbreviations: TNF $\alpha$, Tumor necrosis factor alpha; TGF $\beta$, Transforming growth factor beta; HA, Histamine; PAF, Platelet activating factor; IL, Interleukin; VEGFa, Vascular endothelial growth factor A; FGF2, Fibroblast growth factor 2; SCF, Stem cell factor; PGD 2, Prostaglandin D2; Hep, Heparin; CXCL1, C-X-C-motif chemokine; CCL, C-C motif chemokine ligand; LTD 4 , Leukotriene $\mathrm{D}_{4}$; Cd1d, Cluster of differentiation 1 family glycoprotein; PD-L1, Programmed death-ligand 1; $\mathrm{LTC}_{4}$, Leukotriene $\mathrm{C}_{4}$.

\section{Other Cell Types}

Besides the constitutively ST2-expressing ILC2, Tregs and MCs, there are various cell types, which don't express ST2 at steady state but expression can be induced or is present in minor cellular subsets. These include endothelial cells $(66,67)$, epithelial and epithelial-derived cancer cells $(68,69)$, fibroblasts (34, 70) and other non-immune cell types. Importantly, fibroblasts, endothelial and epithelial cells are also the major cellular sources of IL33 production in the tumor microenvironment (Figure 1) (3-5). The immune cells that respond to IL33 in a ST2dependent manner (in addition to MCs, Tregs and ILC2s) are the innate immune cells: eosinophils, basophils, neutrophils, myeloid derived suppressor cells (MDSC), macrophages (M $\phi)$, natural killer cells (NK), dendritic cells (DC), and the adaptive immune cells: natural killer T cells (NKT), CD4 T cell subsets (Th1/2/17), CD8 T cells, and B cells (Figure 1) (71-80).

\section{IL33 AND MAST CELLS IN GASTROINTESTINAL CANCER}

Various reviews try to group the IL33-responding immune cell types based on their role in tumor growth, whereby MCs, (tumor associated) macrophages and Tregs are considered pro-tumorigenic, while CD8, NK, NKT, and DC conferring predominantly anti-tumorigenic functions $(6,74,77,81)$. Beside 
these "classical activities," for many of these cells both anti- and pro-tumorigenic roles have been described and for most cell types their functions might be tumor-type and -stage dependent.

The role of IL33 in cancer has been reviewed recently $(81,82)$. IL33 expression correlates with poor prognosis in some cancers, but predicts good outcomes in others (77). Likewise for MCs, high mast cell infiltration can correlate either with poor or good prognosis depending on the tumor type (65).

\section{Pre-cancerous Inflammation}

Chronic inflammation or infection often precedes neoplastic transformation. Accordingly, IL33 expression is elevated in colonic epithelial cells and myofibroblasts of ulcerative colitis patients $(83,84)$ and in the chronically inflamed stomachs of patients infected with $H$. pylori or during bouts of acute gastritis $(85,86)$. Meanwhile, increased MC numbers are readily detected in patients with ulcerative colitis, gastritis and various other inflammatory disorders of the GI tract [reviewed in (87)] and have been attributed a disease-promoting role (88).

Conversely, simultaneous ablation of MCP-6/7, mouse orthologs of the human b tryptases TSAB1/2, significantly protected mice from dextran sodium sulfate (DSS)-induced colitis (89). While thi observation suggests that MCs may promote the inflammatory environment that mediates DSSdependent destruction of the epithelial layer, the role of MC during the subsequent "wound-healing reaction" remains less clear. Although, it has been noted that tryptase-expressing MCs persist for several weeks at the site of the original injury (90). Consistent with a role for MC to not only release various leukocyte attracting chemokines, but to also induce proliferative effects on fibroblasts and other "bystander" cells (91). In turn, soluble factors from fibroblasts, including IL-33 can then feedforward on MC and shape their phenotype (92). Indeed, in response to DSS administration, IL33 activated MCs in the colonic epithelium, which subsequently promoted restoration of epithelial barrier function and regeneration of epithelial tissues (93). In accordance with this, Rigoni et al. observed exacerbated colitis in MC-deficient $\mathrm{Kit}^{\mathrm{W}-\mathrm{Sh}}$ mice (94). Collectively these preclinical studies suggest a functional connection between IL33 and MCs during inflammation-associated regeneration of the GI epithelium. Similarly, tumors, "wounds that do not heal," may co-opt these wound-healing associated IL33-mast cell immune responses (95).

\section{Intestinal and Colorectal Cancer}

Although IL33 is elevated in colorectal cancer (CRC) patients when compared to normal tissues, in some studies its levels were reduced when comparing late vs. early stage disease (70, 96-98). Mast cell infiltration is associated with poor prognosis in colorectal cancer patients [reviewed in (65)], and at least one study also associated high IL33 expression with poor survival outcomes for metastatic CRC (99). Meanwhile, IL33ST2 mechanisms underpinning pro- and anti-tumoral roles in CRC have been studied in mice. Maywald et al., observed reduced intestinal polyposis in IL33-deficient $\mathrm{Apc}^{\mathrm{Min}}$ mice, which was associated with a lack of IL33-mediated mast cell and myofibroblast activation (70). A tumor promoting role for
IL33 was confirmed independently (44). However, two separate studies reported elevated tumor burden in MC-deficient $\mathrm{Apc}^{\mathrm{Min}}$ mice when compared to their MC-proficient counterparts (100, 101). Meanwhile, intestinal polyps in $\mathrm{Apc}^{\Delta 468}$ mutant mice have increased IL33 expression and reduced numbers of MCs contribute to the anti-tumoral effect of IL10-deficiency (54) and 5-lipoxygenase-deficiency (102).

In the classic carcinogen-induced mouse model of sporadic colon cancer (6x AOM), colon tumors displayed increased expression of IL33 and ST2. However, mast cell numbers were unchanged, while ST2-deficieny increased number and size of the colon tumors. Surprisingly, the tumor suppressive role of the IL33-ST2 signaling pathway occurred independently of MC abundance, but was mediated by mesenchymal (stem) cells and associated with a strong interferon gamma (IFN $\gamma$ ) gene expression signature (34).

However, in the AOM/DSS inflammation-associated CRC model, ST2-deficient mice had reduced tumor burden, possibly owing to ST2-expressing Tregs although these authors neither investigated the number nor activation status of MCs (43). Using the same model, Mertz et al. also observed reduced tumor burden in ST2-deficient mice (98). Using adoptive bone marrow chimeras, these authors attributed the anti-tumor effect to both the radio-resistant and radio-sensitive cell compartments and demonstrated an involvement of several hematological cell types (98). The latter observation was consistent with earlier work demonstrating reduced colonic tumor burden in $\mathrm{MC}$-deficient $\mathrm{c}-\mathrm{Kit}^{\mathrm{W}-\mathrm{sh}}$ mice following the AOM/DSS challenge (94).

\section{Gastric Cancer}

IL33-mediated spasmolytic polypeptide-expressing metaplasia (SPEM) in the stomach of mice is associated with a strong Th2 cytokine response, suggesting an involvement of MCs (103). In human gastric cancer cell lines, IL33 promoted epithelial-to-mesenchymal transition in vitro and xenograft tumor growth in an ST2-dependent manner (104). Recently, we illustrated that MC numbers are elevated in human gastric cancer specimens and that high expression of an IL33-MC activation gene signature predicts poor survival of intestinaltype gastric cancer in patients (33). Utilizing mouse models, we identified an IL33-MC-macrophage axis promoting gastric cancer growth where either ST2-deficiency, lack of MCs or lack of macrophages all restricted gastric cancer growth in the preclinical $g p 130^{F F}$ mouse model of inflammation-associated gastric cancer. IL33-mediated activation of MCs and subsequent secretion of macrophage attracting factors form part of a mechanism resulting in the accumulation of pro-angiogenic and pro-tumorigenic macrophages in the gastric tumors. In ST2-deficient $g p 130^{F F}$ mice, ILC2 and Treg density was not altered, while frequency of MCs was decreased and associated with reduced tumor growth. Conversely, adoptive transfer of ST2-proficient MC stimulated tumor growth in ST2-deficient $g p 130^{F F}$ mice, demonstrating that IL33-ST2 signaling within MCs is part of the tumor promoting effect of IL33 in gastric cancer (33). 
Other Cancers of the Gastrointestinal Tract IL33 administration promoted the growth of Kras and TGFbR2 mutant biliary tract cancers (105) and in mouse models with constitutively active AKT/YAP pathway $(106,107)$. Moreover, IL33 is overexpressed in human gallbladder cancer patients (108). However, in pancreatic cancer patients high IL33 expression and high number of tumor-infiltrating ILC2s correlated with better survival (41). This is consistent with the observation in a pancreatic cancer mouse model, that IL33 activated tumorassociated ILC2s mediated anti-tumor immunity. MCs were not investigated in this study, even though MC's pancreatic tumor promoting functions are known (109). Finally, IL33 is highly expressed in patients with esophageal squamous cell carcinoma. In corresponding cell lines, IL33 overexpression promoted migration and invasiveness, while IL33 knockdown inhibited the metastatic potential of these cells (110).

\section{THERAPEUTIC TARGETING OF THE IL33-MC AXIS}

In recent years, a number of studies have identified compounds that inhibit IL-33 mediated activation of MCs. Amongst those are natural compounds from plants like berberine (111), methoxyluteolin (112), and resveratrol (113) or ES-62 produced from parasitic worms (114) as well as various other drug classes including didox (synthetic ribonucleotide reductase inhibitor) (115), chondroitin sulfate (glycosaminoglycan) (116), triochastatin A (histone deacetylase inhibitor) (117) and the growth factor TGFb1 (118). However, in all these studies, drug effects were investigated exclusively in vitro. In vivo testing in preclinical animal models is required to increase the impact of these findings and investigate their IL33-MC axis specificity and potential off-target effects.

A promising example for an unbiased high-throughput approach to identify IL33-MC modulating drugs was published by Ramadan et al., They conducted a high-throughput screen of over 70,000 small molecules utilizing an AlphaLISA assay, which measures ST2-Fc fragment binding to IL33 (119). The lead compounds were then demonstrated to exhibit activity in vitro as well as in vivo in mouse models for graft vs. host disease.

\section{Targeting IL33/ST2}

Development and characterization of inhibitors of IL33-ST2 signaling is an active field of research. Various synthetic molecules, antibodies and natural compounds either targeting the IL33-ST2 interaction directly, or inhibiting MyD88-IRAK and other downstream signaling pathways, or disrupting production of mediators are in now pre-clinical testing (74).

Targeting the IL33-ST2 interaction strategies are favored due to the knowledge gained from the naturally occurring soluble ST2 receptor isoform (sST2), a secreted "decoy receptor," which binds IL33 and thereby sequestering the ligand from binding to membrane-bound ST2. High sST2 expression has been associated with anti-tumor responses in several cancers (120). However, the most advanced modalities targeting the IL33-ST2 interaction are antibodies, with five different antiIL33 or anti-ST2 antibodies being tested in clinical phase 1 trials and found to be safe for use in humans (NCT02170337, NCT01928368, NCT02958436, NCT02999711, NCT03112577, NCT02345928, NCT03096795). Currently, there are multiple phase 2 trials ongoing/completed investigating the efficacy of IL33-ST2 inhibition against various allergic and inflammatory diseases and diabetic kidney disease (Table 1A).

To date, no clinical trials have been conducted in cancer patients. Indeed, only a limited number of studies have used IL33ST2 neutralizing antibodies in preclinical tumor models in vivo (Table 1B). Strikingly, all these studies demonstrated anti-tumor effects of anti-IL33 and anti-ST2 antibody treatments. However, as a cautionary tale, multiple studies demonstrate anti-tumor effects upon administration of recombinant IL33 $(34,41)$.

\section{Targeting MCs}

A plethora of strategies to target MC receptors, intracellular signaling components and MC-derived mediators have been tested, with some now being used in the clinic. Traditionally, agents targeting MCs were studied and applied in allergies and related disorders $(129,130)$. Accordingly, mast cell stabilizers, drugs like Cromolyn sodium, Nedocromil, and Lodoxamide, which block MC degranulation are utilized for indications like asthma and other allergic diseases (130).

A number of tyrosine kinase inhibitors including Nilotinib, Sunitinib, Dasatinib, Imatinib, and Masitinib are in clinical trials or in clinical practice as anti-cancer drugs (130). All these small molecule inhibitors have high affinity for the tyrosine kinase receptor KIT, in addition to other tyrosine kinases. KIT is a key molecule for MC development, proliferation, survival and function and inhibition of KIT reduces MC numbers and inhibits their function. For example, Imatinib was shown to reduce asthma symptoms in a MC-dependent manner (131), yet the impact of these TK inhibitors on MCs and their contribution to the anti-tumor effect has not been investigated systematically. In the first instance, it would be important to establish whether tumors with high MC numbers respond better to anti-KIT tyrosine kinase inhibitors.

The field of targeting IL33-ST2 signaling is quickly progressing, with neutralizing antibodies being the most promising agents. While these antibodies advance rapidly in clinical trials for various inflammatory disorders, their use as anti-cancer agents is only just beginning. More work is required to better dissect tumor-promoting from tumor suppressing roles conferred by the IL33-ST2 axis in order to predict in which tumor microenvironment inhibition of IL33-ST2 signaling or MCs will be beneficial.

\section{CHALLENGES FOR THE FIELD}

The importance of IL33 and MCs in GI cancer has been well documented. In recent years, there has been some progress in understanding the mechanisms of how the IL33-MC axis acts 
TABLE 1A | Clinical trials utilizing antibodies targeting IL33/ST2.

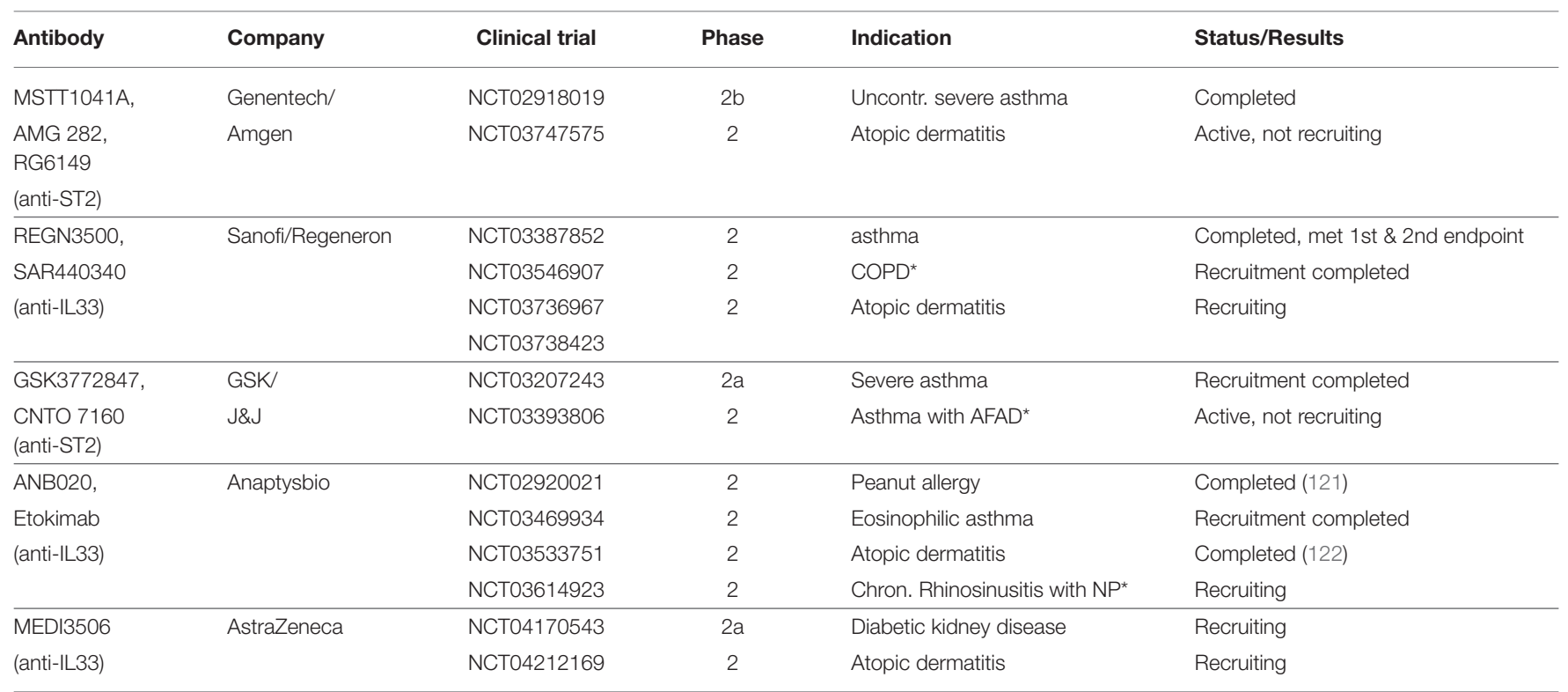

${ }^{*} \mathrm{COPD}$, chronic obstructive pulmonary disease; ${ }^{\star} A F A D$, allergic fungal airway disease; * $N P$, Nasal Polyps.

TABLE 1B | Studies utilizing antibodies IL33/ST2 in tumor models in mice.

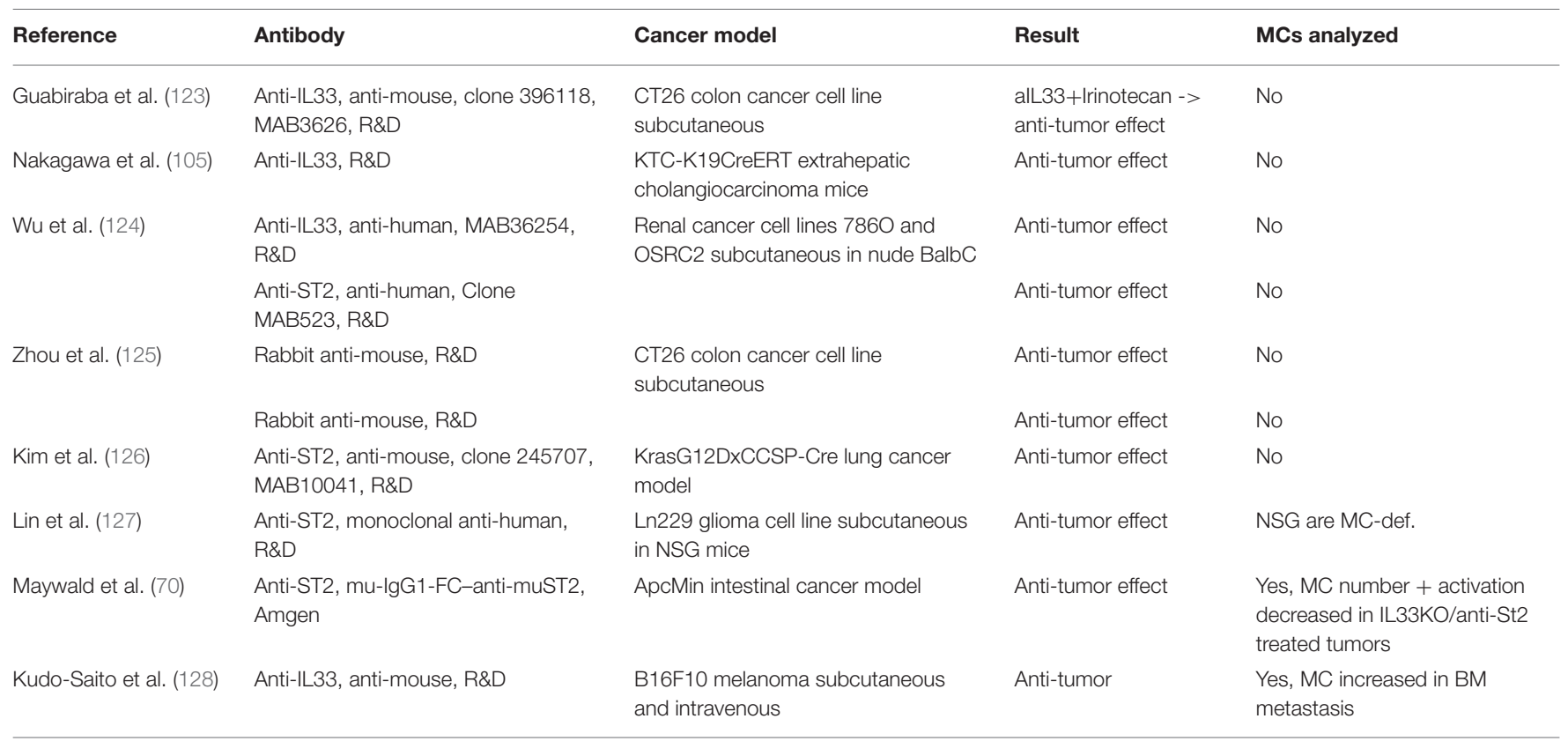

in GI cancers. While there is an increasing interest in targeting this signaling node in various diseases, the few drug candidates currently undergoing clinical testing have not been utilized in cancer trials yet. This is due to the dichotomous actions of IL33 and MCs in cancer. Below we dicuss some of the aspects of IL33 and MC biology which need to be addressed in order to advance the field toward harnessing IL33/MCs targeting as a novel treatment option for GI cancers.

\section{Diversity of Cell Types Responding to IL33}

While there is now ample evidence that the IL33-MC axis is important for many cancers, the multitude of cell types in the TME able to respond to IL33 and mediated either proor anti-tumorigenic effects presents a formidable challenge for predicting the outcome of anti-IL33/anti-ST2 therapies. We propose that a detailed investigation of the spatial distribution of IL33-expressing cells and ST2-presenting responder cells 
in combination with full immunophenotyping of tumors will help addressing these issues. Since oxidation of IL33 in the extracellular space occurs rapidly and drastically reduces its ability to bind ST2 and trigger downstream signaling activation (132), we speculate that only the ST2-expressing cells in close spatial proximity of IL33-rpoducing cells will respond to IL33. Novel technologies like multiplex immunofluorescence microscopy, will allow spatial identification of cell types expressing IL33 and ST2, enabling prediction of responder cell types. Because Tregs and ILC2s are also constitutively expressing ST2, these cell types should be the included in studies attempting to predict anti-tumor effects of IL33ST2 inhibition.

Also, further research is required to better understand the temporal dimension of IL33 secretion and the cell types responding during early vs. late stages of tumorigenesis. Indeed some studies suggest that IL33 expression is decreased in more advanced disease $(97,98)$ while serum levels of IL33 increased in patient with advanced gastric cancer (133). Tissue resident ST2-expressing cells, like MCs and ILC2s are the dominant IL33 responders during the early stages of tumor development. However, it is not known whether these cells can lose their responsiveness to IL33 in the changing tumor microenvironment, for example, by downregulating expression of ST2, nor has it has been investigated whether the dominant IL33 responses shift with increasing tumor size and progression of disease toward ST2positive cells newly recruited into the tumors. Nevertheless, there is significant evidence of the role of MCs and IL33 in late stage cancers, particular in the context of tissue remodeling, epithelial to mesenchymal transition and invasion $(104,128,134,135)$.

\section{Heterogeneity}

Many effects of IL33 are mediated through MC activation. However, the true extent of MC heterogeneity within the TME is not well understood. Only a few whole transcriptome studies are published, all of them were performed on bulk MCs isolated from healthy mice or humans. As part of the FANTOM5 project, Motakis et al. (136) elucidated the transcriptome of human skin MCs and compared against ex vivo cultured MCs. They found MC-specific gene signatures distinguishing the skin MCs from various other cell types, and discovered significant changes in gene expression profiles suggesting significant de-or transdifferentiation associated with in vitro propagation of MCs cultured (136). This warrants careful interpretation of findings obtained from in vitro studies. Transcriptional profiling of MCs from various tissues against other major immune cell lineages, revealed not only distinct differences between the various cell types but also considerable transcriptional heterogeneity between MCs recovered from different tissues (137). Indeed, a recent review suggested to replace the currently used system of histological classification of MCs with a system based on
MC protease expression to more accurately reflect the tissuespecific versatility of MCs (138). Single cell sequencing studies of cancer-associated MCs are required to elucidate the true extent of mast cell heterogeneity to better understand the various biological consequences of mast cell activation in the cancer setting.

\section{Diversity of Mast Cell Activation Signals}

Following on from the initial study by Schmitz et al., the ability of IL33 to activate MCs has been studied extensively (2, 139). However, MCs are key sentinel cells that express many receptors on their surface $(46,140)$, resulting in a multitude of environmental factors able to trigger their activation.

Allergen IgE-mediated activation of MCs was the first to be identified and is well characterized in the context of allergic pathologies, yet many other factors can activate MCs in an IgE-independent manner $(52,139)$.

Numerous studies have shown that IL33-elicited responses in MCs differ from IgE stimulation and that IL33-mediated responses in MCs are modified, and often potentiated, when secondary stimuli like IgE, substance P or IL3 are present $(112,141-144)$. Further research is required to uncover other MC-activating factors present in the tumor microenvironment and how they impact IL33 signaling and MC activation.

\section{CONCLUSIONS}

Diverse functions for both IL33 and mast cells were uncovered in the context of cancer initiation and progression. However, only by focusing on the IL33/MC axis, rather than studying these key regulators of immunity separately, and by utilizing novel technologies, will the full potential of targeting IL33 signaling and $\mathrm{MC}$ activation be discovered and exploited for anti-cancer therapies.

\section{AUTHOR CONTRIBUTIONS}

MFE, MB, and ME: conception, design, writing, reviewing, and editing of the manuscript. All authors: contributed to the article and approved the submitted version.

\section{FUNDING}

This work was made possible through grants from Cancer Council Victoria (CCV) (APP1160708) (MFE), National Health and Medical Research Council (NHMRC) (GNT1143020) (MB), and (1092788) (ME), and Victorian State Government Operational Infrastructure Support. ME also received funding from Ludwig Cancer Research and is a Research Fellow of the NHMRC. 


\section{REFERENCES}

1. Baekkevold ES, Roussigne M, Yamanaka T, Johansen FE, Jahnsen FL, Amalric F, et al. Molecular characterization of NF-HEV, a nuclear factor preferentially expressed in human high endothelial venules. Am J Pathol. (2003) 163:69-79. doi: 10.1016/S0002-9440(10)63631-0

2. Schmitz J, Owyang A, Oldham E, Song Y, Murphy E, McClanahan TK, et al. IL-33, an interleukin-1-like cytokine that signals via the IL-1 receptor-related protein ST2 and induces T helper type 2-associated cytokines. Immunity. (2005) 23:479-90. doi: 10.1016/j.immuni.2005. 09.015

3. Moussion C, Ortega N, Girard JP. The IL-1-like cytokine IL-33 is constitutively expressed in the nucleus of endothelial cells and epithelial cells in vivo: a novel alarmin? PLoS ONE. (2008) 3:e3331. doi: 10.1371/journal.pone.0003331

4. Pichery M, Mirey E, Mercier P, Lefrancais E, Dujardin A, Ortega N, et al. Endogenous IL-33 is highly expressed in mouse epithelial barrier tissues, lymphoid organs, brain, embryos, and inflamed tissues: in situ analysis using a novel Il-33-LacZ gene trap reporter strain. J Immunol. (2012) 188:3488-95. doi: 10.4049/jimmunol.1101977

5. Wasmer MH, Krebs P. The role of IL-33-dependent inflammation in the tumor microenvironment. Front Immunol. (2016) 7:682. doi: 10.3389/fimmu.2016.00682

6. Afferni C, Buccione C, Andreone S, Galdiero MR, Varricchi G, Marone $\mathrm{G}$, et al. The pleiotropic immunomodulatory functions of IL-33 and its implications in tumor immunity. Front Immunol. (2018) 9:2601. doi: 10.3389/fimmu.2018.02601

7. Hsu CL, Bryce PJ. Inducible IL-33 expression by mast cells is regulated by a calcium-dependent pathway. J Immunol. (2012) 189:3421-9. doi: 10.4049/jimmunol.1201224

8. Talabot-Ayer D, Calo N, Vigne S, Lamacchia C, Gabay C, Palmer G.,et al. The mouse interleukin (Il) 33 gene is expressed in a cell type- and stimulusdependent manner from two alternative promoters. J Leukoc Biol. (2012) 91:119-25. doi: 10.1189/jlb.0811425

9. Byers DE, Alexander-Brett J, Patel AC, Agapov E, Dang-Vu G, Jin X, et al. Long-term IL-33-producing epithelial progenitor cells in chronic obstructive lung disease. J Clin Invest. (2013) 123:3967-82. doi: 10.1172/JCI65570

10. Hardman CS, Panova V, McKenzie AN. IL-33 citrine reporter mice reveal the temporal and spatial expression of IL-33 during allergic lung inflammation. Eur J Immunol. (2013) 43:488-98. doi: 10.1002/eji.201242863

11. Wei J, Zhao J, Schrott V, Zhang Y, Gladwin M, Bullock G, et al. Red blood cells store and release interleukin-33. J Investig Med. (2015) 63:806-10. doi: 10.1097/JIM.0000000000000213

12. Liew FY, Girard JP, Turnquist HR. Interleukin-33 in health and disease. Nat Rev Immunol. (2016) 16:676-89. doi: 10.1038/nri.2016.95

13. Molofsky AB, Savage AK, Locksley RM. Interleukin-33 in tissue homeostasis, injury, and inflammation. Immunity. (2015) 42:1005-19. doi: 10.1016/j.immuni.2015.06.006

14. Luthi AU, Cullen SP, McNeela EA, Duriez PJ, Afonina IS, Sheridan C, et al. Suppression of interleukin-33 bioactivity through proteolysis by apoptotic caspases. Immunity. (2009) 31:84-98. doi: 10.1016/j.immuni.2009.05.007

15. Cayrol C, Girard JP. The IL-1-like cytokine IL-33 is inactivated after maturation by caspase-1. Proc Natl Acad Sci USA. (2009) 106:9021-6. doi: 10.1073/pnas.0812690106

16. Nile CJ, Barksby E, Jitprasertwong P, Preshaw PM, Taylor JJ. Expression and regulation of interleukin-33 in human monocytes. Immunology. (2010) 130:172-80. doi: 10.1111/j.1365-2567.2009.03221.x

17. Kovalenko A, Kim JC, Kang TB, Rajput A, Bogdanov K, DittrichBreiholz O, et al. Caspase-8 deficiency in epidermal keratinocytes triggers an inflammatory skin disease. J Exp Med. (2009) 206:2161-77. doi: 10.1084 /jem.20090616

18. Scott IC, Majithiya JB, Sanden C, Thornton P, Sanders PN, Moore T, et al. Interleukin-33 is activated by allergen- and necrosis-associated proteolytic activities to regulate its alarmin activity during epithelial damage. Sci Rep. (2018) 8:3363. doi: 10.1038/s41598-018-21589-2

19. Shlomovitz I, Erlich Z, Speir M, Zargarian S, Baram N, Engler M, et al. Necroptosis directly induces the release of full-length biologically active IL33 in vitro and in an inflammatory disease model. FEBS J. (2019) 286:507-22. doi: $10.1111 /$ febs.14738
20. Rickard JA, ODonnell JA, Evans JM, Lalaoui N, Poh AR, Rogers $\mathrm{T}$, et al. RIPK1 regulates RIPK3-MLKL-driven systemic inflammation and emergency hematopoiesis. Cell. (2014) 157:1175-88. doi: 10.1016/j.cell.2014.04.019

21. Martin NT, Martin MU. Interleukin 33 is a guardian of barriers and a local alarmin. Nat Immunol. (2016) 17:122-31. doi: 10.1038/ni.3370

22. Sanada S, Hakuno D, Higgins LJ, Schreiter ER, McKenzie AN, Lee RT., et al. IL-33 and ST2 comprise a critical biomechanically induced and cardioprotective signaling system. J Clin Invest. (2007) 117:1538-49. doi: 10.1172/JCI30634

23. Ohno T, Oboki K, Kajiwara N, Morii E, Aozasa K, Flavell RA, et al. Caspase1 , caspase- 8 , and calpain are dispensable for IL-33 release by macrophages. $J$ Immunol. (2009) 183:7890-7. doi: 10.4049/jimmunol.0802449

24. Kakkar R, Hei H, Dobner S, Lee RT. Interleukin 33 as a mechanically responsive cytokine secreted by living cells. J Biol Chem. (2012) 287:6941-8. doi: 10.1074/jbc.M111.298703

25. Chen H, Sun Y, Lai L, Wu H, Xiao Y, Ming B, et al. Interleukin-33 is released in spinal cord and suppresses experimental autoimmune encephalomyelitis in mice. Neuroscience. (2015) 308:157-68. doi: 10.1016/j.neuroscience.2015.09.019

26. Lingel A, Weiss TM, Niebuhr M, Pan B, Appleton BA, Wiesmann C, et al. Structure of IL-33 and its interaction with the ST2 and IL-1RAcP receptors-insight into heterotrimeric IL-1 signaling complexes. Structure. (2009) 17:1398-410. doi: 10.1016/j.str.2009.08.009

27. Liu X, Hammel M, He Y, Tainer JA, Jeng US, Zhang L, et al. Structural insights into the interaction of IL-33 with its receptors. Proc Natl Acad Sci USA. (2013) 110:14918-23. doi: 10.1073/pnas.1308651110

28. Ali S, Mohs A, Thomas M, Klare J, Ross R, Schmitz ML, et al. The dual function cytokine IL-33 interacts with the transcription factor NF-kappaB to dampen NF-kappaB-stimulated gene transcription. J Immunol. (2011) 187:1609-16. doi: 10.4049/jimmunol.1003080

29. Carriere V, Roussel L, Ortega N, Lacorre DA, Americh L, Aguilar L, et al. IL-33, the IL-1-like cytokine ligand for ST2 receptor, is a chromatinassociated nuclear factor in vivo. Proc Natl Acad Sci USA. (2007) 104:282-7. doi: $10.1073 /$ pnas.0606854104

30. Hatzioannou A, Banos A, Sakelaropoulos T, Fedonidis C, Vidali MS, Kohne $M$, et al. An intrinsic role of IL-33 in Treg cellmediated tumor immunoevasion. Nat Immunol. (2020) 21:75-85. doi: 10.1038/s41590-019-0555-2

31. Stier MT, Mitra R, Nyhoff EL, Goleniewska K, Zhang J, Puccetti MV, et al. IL-33 Is a cell-intrinsic regulator of fitness during early B cell development. $J$ Immunol. (2019) 203:1457-67. doi: 10.4049/jimmunol.1900408

32. Cayrol C, Girard JP. Interleukin-33 (IL-33): A nuclear cytokine from the IL-1 family. Immunol Rev. (2018) 281:154-68. doi: 10.1111/imr.12619

33. Eissmann MF, Dijkstra C, Jarnicki A, Phesse T, Brunnberg J, Poh AR, et al. IL-33-mediated mast cell activation promotes gastric cancer through macrophage mobilization. Nat Commun. (2019) 10:2735. doi: 10.1038/s41467-019-10676-1

34. Eissmann MF, Dijkstra C, Wouters MA, Baloyan D, Mouradov D, Nguyen $\mathrm{PM}$, et al. Interleukin 33 signaling restrains sporadic colon cancer in an interferon-gamma-dependent manner. Cancer Immunol Res. (2018) 6:40921. doi: 10.1158/2326-6066.CIR-17-0218

35. Schiering C, Krausgruber T, Chomka A, Frohlich A, Adelmann K, Wohlfert $\mathrm{EA}$, et al. The alarmin IL-33 promotes regulatory T-cell function in the intestine. Nature. (2014) 513:564-8. doi: 10.1038/nature13577

36. Moro K, Yamada T, Tanabe M, Takeuchi T, Ikawa T, Kawamoto $\mathrm{H}$, et al. Innate production of $\mathrm{T}(\mathrm{H}) 2$ cytokines by adipose tissueassociated c-Kit(+)Sca-1(+) lymphoid cells. Nature. (2010) 463:540-4. doi: $10.1038 /$ nature 08636

37. Flamar AL, Klose CSN, Moeller JB, Mahlakoiv T, Bessman NJ, Zhang W, et al. Interleukin-33 induces the enzyme tryptophan hydroxylase 1 to promote inflammatory group 2 innate lymphoid cell-mediated immunity. Immunity. (2020) 52:606-19. doi: 10.1016/j.immuni.2020.02.009

38. Cayrol C, Girard JP. IL-33: an alarmin cytokine with crucial roles in innate immunity, inflammation and allergy. Curr Opin Immunol. (2014) 31:31-7. doi: 10.1016/j.coi.2014.09.004

39. Kim BS, Wojno ED, Artis D. Innate lymphoid cells and allergic inflammation. Curr Opin Immunol. (2013) 25:738-44. doi: 10.1016/j.coi.2013.07.013 
40. Molofsky AB, Nussbaum JC, Liang HE, Van Dyken SJ, Cheng LE, Mohapatra $\mathrm{A}$, et al. Innate lymphoid type 2 cells sustain visceral adipose tissue eosinophils and alternatively activated macrophages. J Exp Med. (2013) 210:535-49. doi: 10.1084/jem.20121964

41. Moral JA, Leung J, Rojas LA, Ruan J, Zhao J, Sethna Z, et al. ILC2s amplify PD-1 blockade by activating tissue-specific cancer immunity. Nature. (2020) 579:130-35. doi: 10.1038/s41586-020-2015-4

42. Matta BM, Reichenbach DK, Zhang X, Mathews L, Koehn BH, Dwyer GK, et al. Peri-alloHCT IL-33 administration expands recipient T-regulatory cells that protect mice against acute GVHD. Blood. (2016) 128:427-39. doi: 10.1182/blood-2015-12-684142

43. Pastille E, Wasmer MH, Adamczyk A, Vu VP, Mager LF, Phuong T, et al. The IL-33/ST2 pathway shapes the regulatory $\mathrm{T}$ cell phenotype to promote intestinal cancer. Mucosal Immunol. (2019) 12:990-1003. doi: 10.1038/s41385-019-0176-y

44. He Z, Chen L, Souto FO, Canasto-Chibuque C, Bongers G, Deshpande $\mathrm{M}$, et al. Epithelial-derived IL-33 promotes intestinal tumorigenesis in Apc (Min/+) mice. Sci Rep. (2017) 7:5520. doi: 10.1038/s41598-017-05716-z

45. Meinicke H, Bremser A, Brack M, Akeus P, Pearson C, Bullers S, et al. Tumour-associated changes in intestinal epithelial cells cause local accumulation of KLRG1(+) GATA3 $(+)$ regulatory $\mathrm{T}$ cells in mice. Immunology. (2017) 152:74-88. doi: 10.1111/imm.12750

46. Varricchi G, Galdiero MR, Loffredo S, Marone G, Iannone R, Marone G, et al. Are mast cells MASTers in cancer? Front Immunol. (2017) 8:424. doi: 10.3389/fimmu.2017.00424

47. Holdsworth SR, Summers SA. Role of mast cells in progressive renal diseases. J Am Soc Nephrol. (2008) 19:2254-61. doi: 10.1681/ASN.2008010015

48. Cardamone C, Parente R, Feo GD, Triggiani M. Mast cells as effector cells of innate immunity and regulators of adaptive immunity. Immunol Lett. (2016) 178:10-4. doi: 10.1016/j.imlet.2016.07.003

49. Voehringer D. Protective and pathological roles of mast cells and basophils. Nat Rev Immunol. (2013) 13:362-75. doi: 10.1038/nri3427

50. Saluja R, Ketelaar ME, Hawro T, Church MK, Maurer M, Nawijn MC., et al. The role of the IL-33/IL-1RL1 axis in mast cell and basophil activation in allergic disorders. Mol Immunol. (2015) 63:80-5. doi: 10.1016/j.molimm.2014.06.018

51. Siebenhaar F, Redegeld FA, Bischoff SC, Gibbs BF, Maurer M. Mast cells as drivers of disease and therapeutic targets. Trends Immunol. (2018) 39:15162. doi: 10.1016/j.it.2017.10.005

52. Lyons DO, Pullen NA. Beyond IgE: alternative mast cell activation across different disease States. Int J Mol Sci. (2020) 21:1498. doi: 10.3390/ijms21041498

53. Lefrancais E, Duval A, Mirey E, Roga S, Espinosa E, Cayrol C, et al. Central domain of IL-33 is cleaved by mast cell proteases for potent activation of group-2 innate lymphoid cells. Proc Natl Acad Sci USA. (2014) 111:15502-7. doi: 10.1073/pnas.1410700111

54. Saadalla AM, Osman A, Gurish MF, Dennis KL, Blatner NR, Pezeshki A, et al. Mast cells promote small bowel cancer in a tumor stage-specific and cytokine-dependent manner. Proc Natl Acad Sci USA. (2018) 115:1588-92. doi: 10.1073/pnas.1716804115

55. Metz M, Maurer M. Mast cells-key effector cells in immune responses. Trends Immunol. (2007) 28:234-41. doi: 10.1016/j.it.2007.03.003

56. Oldford SA, Marshall JS. Mast cells as targets for immunotherapy of solid tumors. Mol Immunol. (2015) 63:113-24. doi: 10.1016/j.molimm.2014.02.020

57. Moretti S, Renga G, Oikonomou V, Galosi C, Pariano M, Iannitti RG, et al. A mast cell-ILC2-Th9 pathway promotes lung inflammation in cystic fibrosis. Nat Commun. (2017) 8:14017. doi: 10.1038/ncomms14017

58. Ruoss SJ, Hartmann T, Caughey GH. Mast cell tryptase is a mitogen for cultured fibroblasts. J Clin Invest. (1991) 88:493-9. doi: 10.1172/JCI115330

59. Palm AK, Garcia-Faroldi G, Lundberg M, Pejler G, Kleinau S. Activated mast cells promote differentiation of B cells into effector cells. Sci Rep. (2016) 6:20531. doi: 10.1038/srep20531

60. Gonzalez Roldan N, Orinska Z, Ewers H, Bulfone-Paus S. CD252 regulates mast cell mediated, CD1d-restricted NKT-cell activation in mice. Eur J Immunol. (2016) 46:432-9. doi: 10.1002/eji.201545879

61. Varricchi G, Rossi FW, Galdiero MR, Granata F, Criscuolo G, Spadaro $\mathrm{G}$, et al. Physiological roles of mast cells: collegium internationale allergologicum update 2019. Int Arch Allergy Immunol. (2019) 179:247-61. doi: 10.1159/000500088

62. Bischoff SC. Role of mast cells in allergic and non-allergic immune responses: comparison of human and murine data. Nat Rev Immunol. (2007) 7:93-104. doi: $10.1038 /$ nri2018

63. Danelli L, Frossi B, Gri G, Mion F, Guarnotta C, Bongiovanni L, et al. Mast cells boost myeloid-derived suppressor cell activity and contribute to the development of tumor-favoring microenvironment. Cancer Immunol Res. (2015) 3:85-95. doi: 10.1158/2326-6066.CIR-14-0102

64. Dudeck A, Koberle M, Goldmann O, Meyer N, Dudeck J, Lemmens S, et al. Mast cells as protectors of health. J Aller Clin Immunol. (2019) 144:S4-S18. doi: 10.1016/j.jaci.2018.10.054

65. Rigoni A, Colombo MP, Pucillo C. The role of mast cells in molding the tumor microenvironment. Cancer Microenviron. (2015) 8:167-76. doi: 10.1007/s12307-014-0152-8

66. Cao K, Liao X, Lu J, Yao S, Wu F, Zhu X, et al. IL-33/ST2 plays a critical role in endothelial cell activation and microglia-mediated neuroinflammation modulation. J Neuroinflammation. (2018) 15:136. doi: 10.1186/s12974-018-1169-6

67. Liu J, Wang W, Wang L, Chen S, Tian B, Huang K, et al. IL-33 initiates vascular remodelling in hypoxic pulmonary hypertension by upregulating HIF-1alpha and VEGF expression in vascular endothelial cells. EBioMedicine. (2018) 33:196-210. doi: 10.1016/j.ebiom.2018.06.003

68. Kim JY, Lim SC, Kim G, Yun HJ, Ahn SG, Choi HS. Interleukin-33/ST2 axis promotes epithelial cell transformation and breast tumorigenesis via upregulation of COT activity. Oncogene. (2015) 34:4928-38. doi: 10.1038 /onc. 2014.418

69. He Z, Chen L, Furtado GC, Lira SA. Interleukin 33 regulates gene expression in intestinal epithelial cells independently of its nuclear localization. Cytokine. (2018) 111:146-53. doi: 10.1016/j.cyto.2018.08.009

70. Maywald RL, Doerner SK, Pastorelli L, De Salvo C, Benton SM, Dawson EP, et al. IL-33 activates tumor stroma to promote intestinal polyposis. Proc Natl Acad Sci USA. (2015) 112:E2487-96. doi: 10.1073/pnas.1422445112

71. Komai-Koma M, Gilchrist DS, McKenzie AN, Goodyear CS, Xu D, Liew FY. IL-33 activates B1 cells and exacerbates contact sensitivity. JImmunol. (2011) 186:2584-91. doi: 10.4049/jimmunol.1002103

72. Sattler S, Ling GS, Xu D, Hussaarts L, Romaine A, Zhao H, et al. IL10-producing regulatory B cells induced by IL-33 (Breg(IL-33)) effectively attenuate mucosal inflammatory responses in the gut. J Autoimmun. (2014) 50:107-22. doi: 10.1016/j.jaut.2014.01.032

73. Huang B, Faucette AN, Pawlitz MD, Pei B, Goyert JW, Zhou JZ, et al. Interleukin-33-induced expression of PIBF1 by decidual B cells protects against preterm labor. Nat Med. (2017) 23:128-35. doi: 10.1038/ nm.4244

74. Chan BCL, Lam CWK, Tam LS, Wong CK. IL33: roles in allergic inflammation and therapeutic perspectives. Front Immunol. (2019) 10:364. doi: 10.3389/fimmu.2019.00364

75. Qi L, Zhang Q, Miao Y, Kang W, Tian Z, Xu D, et al. Interleukin-33 activates and recruits natural killer cells to inhibit pulmonary metastatic cancer development. Int J Cancer. (2019) 146:1421-34. doi: 10.1002/ijc. 32779

76. Andersson P, Yang Y, Hosaka K, Zhang Y, Fischer C, Braun H, et al. Molecular mechanisms of IL-33-mediated stromal interactions in cancer metastasis. JCI Insight. (2018) 3:e122375. doi: 10.1172/jci.insight.122375

77. Fournie JJ, Poupot M. The Pro-tumorigenic IL-33 involved in antitumor immunity: a yin and yang cytokine. Front Immunol. (2018) 9:2506. doi: 10.3389/fimmu.2018.02506

78. Sun B, Zhu L, Tao Y, Sun HX, Li Y, Wang P, et al. Characterization and allergic role of IL-33-induced neutrophil polarization. Cell Mol Immunol. (2018) 15:782-93. doi: 10.1038/cmi.2017.163

79. Johnston LK, Hsu CL, Krier-Burris RA, Chhiba KD, Chien KB, McKenzie A, et al. IL-33 precedes IL-5 in regulating eosinophil commitment and is required for eosinophil homeostasis. J Immunol. (2016) 197:3445-53. doi: 10.4049/jimmunol.1600611

80. Lucarini V, Ziccheddu G, Macchia I, La Sorsa V, Peschiaroli F, Buccione C, et al. IL-33 restricts tumor growth and inhibits pulmonary metastasis in melanoma-bearing mice through eosinophils. Oncoimmunology. (2017) 6:e1317420. doi: 10.1080/2162402X.2017.1317420 
81. Larsen KM, Minaya MK, Vaish V, Pena MMO. The role of IL33/ST2 pathway in tumorigenesis. Int J Mol Sci. (2018) 19:2676. doi: 10.3390/ijms 19092676

82. Akimoto M, Takenaga K. Role of the IL-33/ST2L axis in colorectal cancer progression. Cell Immunol. (2019) 343:103740. doi: 10.1016/j.cellimm.2017.12.014

83. Kobori A, Yagi Y, Imaeda H, Ban H, Bamba S, Tsujikawa T, et al. Interleukin33 expression is specifically enhanced in inflamed mucosa of ulcerative colitis. J Gastroenterol. (2010) 45:999-1007. doi: 10.1007/s00535-010-0245-1

84. Pastorelli L, Garg RR, Hoang SB, Spina L, Mattioli B, Scarpa M, et al. Epithelial-derived IL-33 and its receptor ST2 are dysregulated in ulcerative colitis and in experimental Th1/Th2 driven enteritis. Proc Natl Acad Sci USA. (2010) 107:8017-22. doi: 10.1073/pnas.0912678107

85. Lv YP, Teng YS, Mao FY, Peng LS, Zhang JY, Cheng P, et al. Helicobacter pylori-induced IL-33 modulates mast cell responses, benefits bacterial growth, and contributes to gastritis. Cell Death Dis. (2018) 9:457. doi: 10.1038/s41419-018-0493-1

86. Shahi H, Reiisi S, Bahreini R, Bagheri N, Salimzadeh L, Shirzad H. Association between Helicobacter pylori cagA, babA2 virulence factors and gastric mucosal interleukin-33 mRNA expression and clinical outcomes in dyspeptic patients. Int J Mol Cell Med. (2015) 4:227-34.

87. Bischoff SC. Mast cells in gastrointestinal disorders. Eur J Pharmacol. (2016) 778:139-45. doi: 10.1016/j.ejphar.2016.02.018

88. Nakajima S, Bamba N, Hattori T. Histological aspects and role of mast cells in Helicobacter pylori-infected gastritis. Aliment Pharmacol Ther. (2004) 20 Suppl 1:165-70. doi: 10.1111/j.1365-2036.2004.01974.x

89. Hamilton MJ, Sinnamon MJ, Lyng GD, Glickman JN, Wang X, Xing W, et al. Essential role for mast cell tryptase in acute experimental colitis. Proc Natl Acad Sci USA. (2011) 108:290-5. doi: 10.1073/pnas.1005758108

90. Iba Y, Shibata A, Kato M, Masukawa T. Possible involvement of mast cells in collagen remodeling in the late phase of cutaneous wound healing in mice. Int Immunopharmacol. (2004) 4:1873-80. doi: 10.1016/j.intimp.2004. 08.009

91. Noli C, Miolo A. The mast cell in wound healing. Vet Dermatol. (2001) 12:303-13. doi: 10.1046/j.0959-4493.2001.00272.x

92. Kaieda S, Shin K, Nigrovic PA, Seki K, Lee RT, Stevens RL, et al. Synovial fibroblasts promote the expression and granule accumulation of tryptase via interleukin-33 and its receptor ST-2 (IL1RL1). J Biol Chem. (2010) 285:21478-86. doi: 10.1074/jbc.M110.114991

93. He Z, Song J, Hua J, Yang M, Ma Y, Yu T, et al. Mast cells are essential intermediaries in regulating IL-33/ST2 signaling for an immune network favorable to mucosal healing in experimentally inflamed colons. Cell Death Dis. (2018) 9:1173. doi: 10.1038/s41419-018-1223-4

94. Rigoni A, Bongiovanni L, Burocchi A, Sangaletti S, Danelli L, Guarnotta C, et al. Mast cells infiltrating inflamed or transformed gut alternatively sustain mucosal healing or tumor growth. Cancer Res. (2015) 75:3760-70. doi: 10.1158/0008-5472.CAN-14-3767

95. Dvorak HF. Tumors: wounds that do not heal-redux. Cancer Immunol Res. (2015) 3:1-11. doi: 10.1158/2326-6066.CIR-14-0209

96. Liu X, Zhu L, Lu X, Bian H, Wu X, Yang W, et al. IL-33/ST2 pathway contributes to metastasis of human colorectal cancer. Biochem Biophys Res Commun. (2014) 453:486-92. doi: 10.1016/j.bbrc.2014.09.106

97. Cui G, Qi H, Gundersen MD, Yang H, Christiansen I, Sorbye SW, et al. Dynamics of the IL-33/ST2 network in the progression of human colorectal adenoma to sporadic colorectal cancer. Cancer Immunol Immunother. (2015) 64:181-90. doi: 10.1007/s00262-014-1624-x

98. Mertz KD, Mager LF, Wasmer MH, Thiesler T, Koelzer VH, Ruzzante G, et al. The IL-33/ST2 pathway contributes to intestinal tumorigenesis in humans and mice. Oncoimmunology. (2016) 5:e1062966. doi: 10.1080/2162402X.2015.1062966

99. Fang M, Li Y, Huang K, Qi S, Zhang J, Zgodzinski W, et al. IL33 promotes colon cancer cell stemness via JNK activation and macrophage recruitment. Cancer Res. (2017) 77:2735-45. doi: 10.1158/0008-5472.CAN16-1602

100. Bodduluri SR, Mathis S, Maturu P, Krishnan E, Satpathy SR, Chilton PM, et al. Mast cell-dependent $\mathrm{CD} 8(+)$ T-cell recruitment mediates immune surveillance of intestinal tumors in $\mathrm{Apc}(\mathrm{Min} /+)$ mice. Cancer Immunol Res. (2018) 6:332-47. doi: 10.1158/2326-6066.CIR-17-0424
101. Sinnamon MJ, Carter KJ, Sims LP, Lafleur B, Fingleton B, Matrisian LM., et al. A protective role of mast cells in intestinal tumorigenesis. Carcinogenesis. (2008) 29:880-6. doi: 10.1093/carcin/bgn040

102. Cheon EC, Khazaie K, Khan MW, Strouch MJ, Krantz SB, Phillips $\mathrm{J}$, et al. Mast cell 5-lipoxygenase activity promotes intestinal polyposis in APCDelta468 mice. Cancer Res. (2011) 71:1627-36. doi: 10.1158/0008-5472.CAN-10-1923

103. Petersen CP, Meyer AR, De Salvo C, Choi E, Schlegel C, Petersen A, et al. A signalling cascade of IL-33 to IL-13 regulates metaplasia in the mouse stomach. Gut. (2018) 67:805-17. doi: 10.1136/gutjnl-2016-312779

104. Zhou Q, Wu X, Wang X, Yu Z, Pan T, Li Z, et al. The reciprocal interaction between tumor cells and activated fibroblasts mediated by TNF-alpha/IL33/ST2L signaling promotes gastric cancer metastasis. Oncogene. (2020) 39:1414-28. doi: 10.1038/s41388-019-1078-x

105. Nakagawa H, Suzuki N, Hirata Y, Hikiba Y, Hayakawa Y, Kinoshita H, et al. Biliary epithelial injury-induced regenerative response by IL-33 promotes cholangiocarcinogenesis from peribiliary glands. Proc Natl Acad Sci USA. (2017) 114:E3806-E15. doi: 10.1073/pnas.1619416114

106. Li J, Razumilava N, Gores GJ, Walters S, Mizuochi T, Mourya R, et al. Biliary repair and carcinogenesis are mediated by IL-33-dependent cholangiocyte proliferation. J Clin Invest. (2014) 124:3241-51. doi: 10.1172/JCI73742

107. Yamada D, Rizvi S, Razumilava N, Bronk SF, Davila JI, Champion MD, et al. IL-33 facilitates oncogene-induced cholangiocarcinoma in mice by an interleukin-6-sensitive mechanism. Hepatology. (2015) 61:1627-42. doi: $10.1002 /$ hep. 27687

108. Tomioka Y, Sung YN, Sawada R, Hong SM, Akita M, Itoh T, et al. IL33 overexpression in gallbladder cancers associated with pancreatobiliary maljunction. Histopathology. (2019) 75:365-75. doi: 10.1111/his.13863

109. Longo V, Tamma R, Brunetti O, Pisconti S, Argentiero A, Silvestris N, et al. Mast cells and angiogenesis in pancreatic ductal adenocarcinoma. Clin Exp Med. (2018) 18:319-23. doi: 10.1007/s10238-018-0493-6

110. Yue Y, Lian J, Wang T, Luo C, Yuan Y, Qin G, et al. Interleukin-33-nuclear factor-kappaB-CCL2 signaling pathway promotes progression of esophageal squamous cell carcinoma by directing regulatory T cells. Cancer Sci. (2019) 111:795-806. doi: 10.1111/cas.14293

111. Li W, Yin N, Tao W, Wang Q, Fan H, Wang Z., et al. Berberine suppresses IL-33-induced inflammatory responses in mast cells by inactivating NFkappaB and p38 signaling. Int Immunopharmacol. (2019) 66:82-90. doi: 10.1016/j.intimp.2018.11.009

112. Taracanova A, Tsilioni I, Conti P, Norwitz ER, Leeman SE, Theoharides TC., et al. Substance P and IL-33 administered together stimulate a marked secretion of IL-1beta from human mast cells, inhibited by methoxyluteolin. Proc Natl Acad Sci USA. (2018) 115:E9381-E90. doi: 10.1073/pnas.1810133115

113. Nakajima S, Ishimaru K, Kobayashi A, Yu G, Nakamura Y, Oh-Oka $\mathrm{K}$, et al. Resveratrol inhibits IL-33-mediated mast cell activation by targeting the MK2/3-PI3K/Akt axis. Sci Rep. (2019) 9:18423. doi: 10.1038/s41598-019-54878-5

114. Ball DH, Al-Riyami L, Harnett W, Harnett MM. IL-33/ST2 signalling and crosstalk with FcepsilonRI and TLR4 is targeted by the parasitic worm product, ES-62. Sci Rep. (2018) 8:4497. doi: 10.1038/s41598-018-22716-9

115. Caslin HL, McLeod JAA, Spence AJ, Qayum AA, Kolawole EM, Taruselli MT, et al. Didox (3,4-dihydroxybenzohydroxamic acid) suppresses IL-33induced cytokine production in primary mouse mast cells. Cell Immunol. (2017) 319:10-6. doi: 10.1016/j.cellimm.2017.04.013

116. Gross AR, Theoharides TC. Chondroitin sulfate inhibits secretion of TNF and CXCL8 from human mast cells stimulated by IL-33. Biofactors. (2019) 45:49-61. doi: 10.1002/biof.1464

117. Krajewski D, Kaczenski E, Rovatti J, Polukort S, Thompson C, Dollard $\mathrm{C}$, et al. Epigenetic regulation via altered histone acetylation results in suppression of mast cell function and mast cell-mediated food allergic responses. Front Immunol. (2018) 9:2414. doi: 10.3389/fimmu.2018.02414

118. Ndaw VS, Abebayehu D, Spence AJ, Paez PA, Kolawole EM, Taruselli MT, et al. TGF-beta1 Suppresses IL-33-Induced Mast Cell Function. J Immunol. (2017) 199:866-73. doi: 10.4049/jimmunol.1601983

119. Ramadan AM, Daguindau E, Rech JC, Chinnaswamy K, Zhang J, Hura GL, et al. From proteomics to discovery of first-in-class ST2 inhibitors active in vivo. JCI Insight. (2018) 3:e99208. doi: 10.1172/jci.insight.99208 
120. Chang $\mathrm{CP}, \mathrm{Hu} \mathrm{MH}$, Hsiao YP, Wang YC. ST2 signaling in the tumor microenvironment. Adv Exp Med Biol. (2020) 1240:83-93. doi: 10.1007/978-3-030-38315-2_7

121. Chinthrajah S, Cao S, Liu C, Lyu SC, Sindher SB, Long A, et al. Phase 2a randomized, placebo-controlled study of anti-IL-33 in peanut allergy. JCI Insight. (2019) 4:e131347. doi: 10.1172/jci.insight.131347

122. Chen YL, Gutowska-Owsiak D, Hardman CS, Westmoreland M, MacKenzie T, Cifuentes L, et al. Proof-of-concept clinical trial of etokimab shows a key role for IL-33 in atopic dermatitis pathogenesis. Sci Transl Med. (2019) 11:eaax2945. doi: 10.1126/scitranslmed.aax2945

123. Guabiraba R, Besnard AG, Menezes GB, Secher T, Jabir MS, Amaral SS, et al. IL-33 targeting attenuates intestinal mucositis and enhances effective tumor chemotherapy in mice. Mucosal Immunol. (2014) 7:1079-93. doi: $10.1038 / \mathrm{mi} .2013 .124$

124. Wu CW, Wu YG, Cheng C, Hong ZD, Shi ZM, Lin SQ, et al. Interleukin33 predicts poor prognosis and promotes renal cell carcinoma cell growth through its receptor ST2 and the JNK signaling pathway. Cell Physiol Biochem. (2018) 47:191-200. doi: 10.1159/000489766

125. Zhou Y, Ji Y, Wang H, Zhang H, Zhou H. IL-33 Promotes the development of colorectal cancer through inducing tumor-infiltrating ST2L(+) regulatory $\mathrm{T}$ cells in mice. Technol Cancer Res Treat. (2018) 17:1533033818780091. doi: 10.1177/1533033818780091

126. Kim BS, Clinton J, Wang Q, Chang SH. Targeting ST2 expressing activated regulatory $\mathrm{T}$ cells in Kras-mutant lung cancer. Oncoimmunology. (2020) 9:1682380. doi: 10.1080/2162402X.2019.1682380

127. Lin L, Li Y, Liu M, Li Q, Liu Q, Li R., et al. The Interleukin-33/ST2 axis promotes glioma mesenchymal transition, stemness and TMZ resistance via JNK activation. Aging. (2020) 12:1685-703. doi: 10.18632/aging.102707

128. Kudo-Saito C, Miyamoto T, Imazeki H, Shoji H, Aoki K, Boku N., et al. IL33 is a key driver of treatment resistance of cancer. Cancer Res. (2020) 80:1981-90. doi: 10.1158/0008-5472.CAN-19-2235

129. Cildir G, Pant H, Lopez AF, Tergaonkar V. The transcriptional program, functional heterogeneity, and clinical targeting of mast cells. J Exp Med. (2017) 214:2491-506. doi: 10.1084/jem.20170910

130. Zhang T, Finn DF, Barlow JW, Walsh JJ. Mast cell stabilisers. Eur J Pharmacol. (2016) 778:158-68. doi: 10.1016/j.ejphar.2015.05.071

131. Cahill KN, Katz HR, Cui J, Lai J, Kazani S, Crosby-Thompson A, et al. KIT Inhibition by imatinib in patients with severe refractory asthma. N Engl J Med. (2017) 376:1911-20. doi: 10.1056/NEJMoa 1613125

132. Cohen ES, Scott IC, Majithiya JB, Rapley L, Kemp BP, England E, et al. Oxidation of the alarmin IL-33 regulates ST2-dependent inflammation. Nat Commun. (2015) 6:8327. doi: 10.1038/ncomms9327

133. Sun P, Ben Q, Tu S, Dong W, Qi X, Wu Y., et al. Serum interleukin33 levels in patients with gastric cancer. Dig Dis Sci. (2011) 56:3596-601. doi: 10.1007/s10620-011-1760-5

134. Lv Y, Zhao Y, Wang X, Chen N, Mao F, Teng Y, et al. Increased intratumoral mast cells foster immune suppression and gastric cancer progression through TNF-alpha-PD-L1 pathway. J Immunother Cancer. (2019) 7:54. doi: 10.1186/s40425-019-0530-3

135. Visciano C, Liotti F, Prevete N, Cali G, Franco R, Collina F, et al. Mast cells induce epithelial-to-mesenchymal transition and stem cell features in human thyroid cancer cells through an IL-8-Akt-Slug pathway. Oncogene. (2015) 34:5175-86. doi: 10.1038/onc.2014.441

136. Motakis E, Guhl S, Ishizu Y, Itoh M, Kawaji H, de Hoon M, et al. Redefinition of the human mast cell transcriptome by deep-CAGE sequencing. Blood. (2014) 123:e58-67. doi: 10.1182/blood-2013-02-483792

137. Dwyer DF, Barrett NA, Austen KF, Consortium Immunological Genome Project. Expression profiling of constitutive mast cells reveals a unique identity within the immune system. Nat Immunol. (2016) 17:878-87. doi: $10.1038 /$ ni.3445

138. Frossi B, Mion F, Sibilano R, Danelli L, Pucillo CEM Is it time for a new classification of mast cells? What do we know about mast cell heterogeneity? Immunol Rev. (2018) 282:35-46. doi: 10.1111/imr.12636

139. Redegeld FA, Yu Y, Kumari S, Charles N, Blank U. Non-IgE mediated mast cell activation. Immunol Rev. (2018) 282:87-113. doi: 10.1111/imr.12629

140. Elieh Ali Komi D, Grauwet K. Role of mast cells in regulation of $\mathrm{T}$ cell responses in experimental and clinical settings. Clin Rev Allergy Immunol. (2018) 54:432-45. doi: 10.1007/s12016-017-8646-z

141. Chhiba KD, Hsu CL, Berdnikovs S, Bryce PJ. Transcriptional heterogeneity of mast cells and basophils upon activation. J Immunol. (2017) 198:4868-78. doi: 10.4049/jimmunol.1601825

142. Cop N, Ebo DG, Bridts CH, Elst J, Hagendorens MM, Mertens C, et al. Influence of IL-6, IL-33, and TNF-alpha on human mast cell activation: Lessons from single cell analysis by flow cytometry. Cytometry B Clin Cytom. (2018) 94:405-11. doi: 10.1002/cyto.b.21547

143. Ronnberg E, Ghaib A, Ceriol C, Enoksson M, Arock M, Safholm J, et al. Divergent effects of acute and prolonged interleukin 33 exposure on mast cell IgE-mediated functions. Front Immunol. (2019) 10:1361. doi: 10.3389/fimmu.2019.01361

144. Drube S, Weber F, Loschinski R, Beyer M, Rothe M, Rabenhorst A, et al. Subthreshold IKK activation modulates the effector functions of primary mast cells and allows specific targeting of transformed mast cells. Oncotarget. (2015) 6:5354-68. doi: 10.18632/oncotarget.3022

Conflict of Interest: The authors declare that the research was conducted in the absence of any commercial or financial relationships that could be construed as a potential conflict of interest.

Copyright (c) 2020 Eissmann, Buchert and Ernst. This is an open-access article distributed under the terms of the Creative Commons Attribution License (CC BY). The use, distribution or reproduction in other forums is permitted, provided the original author(s) and the copyright owner(s) are credited and that the original publication in this journal is cited, in accordance with accepted academic practice. No use, distribution or reproduction is permitted which does not comply with these terms. 